\title{
Elevated oxygen demand in a case of COVID-19 with severe ARDS: a point for optimal oxygenation therapy including ECMO management
}

\section{Taku Oshima ( $\sim$ t_oshima@chiba-u.jp)}

Chiba University Graduate School of Medicine https://orcid.org/0000-0002-3868-8272

\section{Takehiko Oami}

Department of Emergency and Critical Care Medicine, Chiba University Graduate School of Medicine Mana Yamashiro

Department of Emergency and Critical Care Meidicine, Chiba University Graduate School of Medicine Akiko Higashi

Department of Emergency and Critical Care Medicine, Chiba University Graduate School of Medicine Yosuke Hayashi

Department of Emergency and Critical Care Medicine, Chiba University Graduate School of Medicine Natsumi Suga

Department of Emergency and Critical Care Medicine, Chiba University Graduate School of Medicine Shin Takayanagi

Department of Infectious Diseases, Chiba University Hospital

\section{Seiichiro Sakao}

Department of Respirology, Chiba University Graduate School of Medicine

\section{Taka-aki Nakada}

Department of Emergency and Critical Care Medicine, Chiba University Graduate School of Medicine

\section{Case report}

Keywords: Coronavirus disease 2019 (COVID-19), SARS-CoV-2, acute respiratory distress syndrome (ARDS), VV-ECMO, indirect calorimetry, oxygen consumption (VO2)

Posted Date: August 6th, 2020

DOI: https://doi.org/10.21203/rs.3.rs-51286/v1

License: (c) (1) This work is licensed under a Creative Commons Attribution 4.0 International License. Read Full License 


\section{Abstract}

Background: Coronavirus disease 2019 (COVID-19) caused by SARS-CoV-2 has become a global pandemic, and those developing critically ill conditions have been reported to have mortality in the range of $39 \%$ to $61 \%$. Due to the lack of definitive treatments, mechanical ventilation and supportive oxygenation therapy are key management strategies for the survival of patients with acute respiratory distress syndrome (ARDS). Optimizing oxygenation therapy is mandatory to treat patients with severe respiratory failure, to sufficiently compensate for the oxygen $\left(\mathrm{O}_{2}\right)$ demand. We experienced a case of severe ARDS due to COVID-19 successfully treated with extracorporeal membrane oxygenation (ECMO) after increasing oxygen delivery according to $\mathrm{O}_{2}$ consumption measurement by indirect calorimetry

Case Presentation: A 29-year-old obese but otherwise healthy man was hospitalized for treatment of COVID-19 pneumonia presenting with a 4-day history of persisting cough, high fever, and dyspnea. Mechanical ventilation, nitric oxide inhalation, and prone positioning were initiated in the ICU against severe respiratory dysfunction. Indirect calorimetry on the $3^{\text {rd }}$ and $6^{\text {th }} I C U$ days revealed persistent elevation of oxygen consumption $\left(\mathrm{VO}_{2}\right)$ of $380 \mathrm{~mL} / \mathrm{min}$. Veno-venous ECMO was initiated on the $7^{\text {th }}$ ICU day after further deterioration of respiratory failure. Periodic events of $\mathrm{SpO}_{2}$ decline due to effortful breathing was not resolved by neuromuscular blockade in attempt to reduce $\mathrm{O}_{2}$ consumption. Increasing the ECMO flow induced hemolysis and hyperkalemia despite the use of large bore cannulas and ECMO circuit free of clots and defects. The hemoglobin management level was elevated from $10 \mathrm{~g} / \mathrm{dL}$ to 13 $\mathrm{g} / \mathrm{dL}$ to increase blood oxygen capacity, enabling the reduction of ECMO flow while attenuating respiratory effort and maintaining $\mathrm{SpO}_{2}$. Lung protective ventilation strategy and prone positioning were continued for successful weaning from ECMO on the $16^{\text {th }} \mathrm{ICU}$ day, and the ventilator on the $18^{\text {th }}$ ICU day.

Conclusion: The present case of severe ARDS due to COVID-19 was successfully treated with ECMO. Enhancing oxygen delivery was crucial to compensate for the elevated $\mathrm{O}_{2}$ demand. Measuring $\mathrm{O}_{2}$ consumption by indirect calorimetry can elucidate the oxygen demand for optimizing the oxygenation therapy for successful management and survival of critically ill COVID-19 patients.

\section{Background}

Coronavirus disease 2019 (COVID-19) caused by SARS-CoV-2 has become a global pandemic (1-3), and those developing critically ill conditions have been reported to have mortality in the range of $39 \%$ to $61 \%$ (4-6). Due to the lack of definitive treatments prove effective for COVID-19, mechanical ventilation and supportive oxygenation therapy are key management strategies for the survival of patients with acute respiratory distress syndrome (ARDS) (7).

The goal of oxygenation therapy for ARDS is to provide sufficient oxygen $\left(\mathrm{O}_{2}\right)$ to meet the demand of the whole-body metabolism. Hypoxia can occur when oxygen delivery insufficiently compensates for the $\mathrm{O}_{2}$ demand, either as a result of reduced oxygen uptake or the excessive elevation of oxygen consumption. 
COVID-19 is suggested to induce severe systemic inflammation $(8,9)$, possibly leading to hypermetabolism and elevated $\mathrm{O}_{2}$ consumption.

For progressive respiratory failure despite optimal conventional management such as prone positioning and nitric oxide (NO) administration, extracorporeal membrane oxygenation (ECMO) support is indicated $(10,11)$. Moreover, measures to increase the efficacy of $\mathrm{O}_{2}$ supplementation become critical when $\mathrm{O}_{2}$ demand exceeds delivery, and reduction of $\mathrm{O}_{2}$ consumption is not feasible. However, methods to determine $\mathrm{O}_{2}$ demand of COVID-19 patients have not been well described to date.

Here, we encountered a case of severe ARDS due to COVID-19 successfully treated with ECMO by optimizing oxygen delivery against persistent elevation of $\mathrm{O}_{2}$ demand revealed by indirect calorimetry.

\section{Case Presentation}

A 29-year old male admitted to a clinic after 4 days of persisting cough, high fever, and dyspnea, without gastrointestinal symptoms or loss of taste and smell. He was obese with body mass index (BMI) of 31.9 $\mathrm{kg} / \mathrm{m}^{2}$ (height $168 \mathrm{~cm}$, weight $90.0 \mathrm{~kg}$ ), but otherwise presented no underlying pathologies, did not travel abroad and worked at home for at least 14 days prior to the onset of the symptoms. He was diagnosed positive for SARS-CoV-2 polymerase chain reaction test the day after his admission and referred to our hospital for treatment of COVID-19 pneumonia. His brother, a nursing home employee, living in the same household was later diagnosed SARS-CoV-2 positive.

He was conscious and communicated verbally upon admission but presented high fever and tachypnea of 30 /minute, with persisting cough requiring $6 \mathrm{~L} / \mathrm{min}$ of $\mathrm{O}_{2}$ to maintain $\mathrm{SpO}_{2} 95 \%$. Blood tests revealed non-bacterial inflammatory signs, with white blood cell count of $5,900 / \mathrm{mm}^{3}$ with slightly reduced lymphocyte count of $985 / \mathrm{mm}^{3}$, CRP $5.29 \mathrm{mg} / \mathrm{dL}$, procalcitonin $0.14 \mathrm{ng} / \mathrm{mL}$, and interleukin- 686.8 $\mathrm{pg} / \mathrm{mL}$ [Table 1]. He also presented bilateral ground-glass opacities and patchy consolidation on the lung computed tomography (CT) scan, typical findings of COVID-19 pneumonia [Figure 1a, 2a]. Favipiravir and azithromycin were started on the day of hospitalization, but $\mathrm{SpO}_{2}$ fell below $92 \%$ under $15 \mathrm{~L} / \mathrm{min} \mathrm{O}_{2}$ reservoir mask on day 3 , when he was intubated and admitted to the intensive care unit (ICU).

Mechanical ventilation was initiated, and nitric oxide was inhaled at $20 \mathrm{ppm}$ for oxygenation support. Chest $X$ ray on the $3^{\text {rd }} I C U$ day presented severe progression of bilateral infiltrate, prompting prone positioning for lung recruitment. Indirect calorimetry [E-COVX, General Electric, USA] was conducted on the $3^{\text {rd }} \mathrm{ICU}$ day for the evaluation of energy and $\mathrm{O}_{2}$ consumption [Table 2]. The resting energy expenditure (REE) ranged from 1832 to $2583 \mathrm{kcal} /$ day, corresponding to $\mathrm{O}_{2}$ consumption volume $\left(\mathrm{VO}_{2}\right)$ of 275 and $380 \mathrm{ml} / \mathrm{min}$, respectively, while being deeply sedated with midazolam and fentanyl to achieve -5 points on the Richmond agitation-sedation scale (RASS). Repeated evaluation on the $6^{\text {th }}$ ICU day revealed sustained REE of $2530 \mathrm{kcal} /$ day with $\mathrm{VO}_{2}$ of $380 \mathrm{ml} / \mathrm{min}$. 
His lung oxygenation gradually deteriorated and required positive end-expiratory pressure (PEEP) $14 \mathrm{~cm}$ $\mathrm{H}_{2} \mathrm{O}$ for $\mathrm{PaO}_{2} / \mathrm{FiO}_{2}$ of 85 on the $6^{\text {th }}$ ICU day, leading to the decision to start veno-venous (VV) ECMO [centrifugal pump: RotaFlow ${ }^{\circledR}$, Maquet Getinge, Rastatt, Germany; artificial lung: BIOCUBE $6000 \AA$, NIPRO, Osaka, Japan; drainage and outflow catheter: $25 \mathrm{Fr}$.HLS cannula ${ }^{\circledR}, 19 \mathrm{Fr}$.HLS cannula ${ }^{\circledR}$, Maquet Getinge, Rastatt, Germany] on the $7^{\text {th }}$ ICU day [Figure 2b]. ECMO was initiated at blood flow of $4 \mathrm{~L} / \mathrm{min}$, with $7 \mathrm{~L} / \mathrm{min}$ of $100 \% \mathrm{O}_{2}$ as sweep gas, with blood temperature managed at $37.0^{\circ} \mathrm{C}$. NO was paused and ventilatory support was minimized [bi-level pressure control ventilation with $\mathrm{FiO}_{2} 0.4$ at PEEP $10 \mathrm{~cm} \mathrm{H}_{2} \mathrm{O}$ and driving pressure $5 \mathrm{~cm} \mathrm{H}_{2} \mathrm{O}$ ] as lung protective strategy, while prone positioning was continued.

Events of excessive respiratory effort were observed after the initiation of VV-ECMO, with a simultaneous $\mathrm{SpO}_{2}$ decline below $80 \%$. As the patient was already deeply sedated with midazolam and fentanyl to achieve Richmond agitation-sedation scale of -5 , neuromuscular blocking with rocuronium was added to attenuate the excessive respiratory effort, thus to avoid lung damage and to reduce $\mathrm{O}_{2}$ consumption. However, unresolved $\mathrm{SpO}_{2}$ decline with gradual increase of lactate from 1.2 to $1.8 \mathrm{mmol} / \mathrm{l}$ under stable systemic circulation necessitated increasing the ECMO blood flow to $4.5 \mathrm{~L} / \mathrm{min}$. However, the increased flow induced hemolysis and hyperkalemia, without obvious signs of sucking down or clot formation in the ECMO circuit and artificial lung. We strategically elevated the hemoglobin management level from 10 $\mathrm{g} / \mathrm{dL}$ to $13 \mathrm{~g} / \mathrm{dL}$ to enhance the blood oxygen capacity and thus the $\mathrm{O}_{2}$ delivery, enabling the reduction of the ECMO blood flow to resolve hemolysis.

Chest X-ray findings presented gradual recovery from bilateral infiltration, enabling reduction of ECMO flow to $2.6 \mathrm{~L} / \mathrm{min}$ for sufficient oxygenation by the $12^{\text {th }} \mathrm{ICU}$ day. He was weaned off from ECMO on the $16^{\text {th }}$ ICU day after 120 minutes of a successful sweep gas cessation trial. He was successfully weaned off from the ventilator on $18^{\text {th }}$ ICU day and was transferred back to the ward on the $23^{\text {rd }}$ ICU day. After 23 days of rehabilitation in the ward, he was discharged home on his $46^{\text {th }}$ day of hospitalization [Figure $1 \mathrm{~b}$, 2c].

\section{Discussion And Conclusions}

We experienced a case of young COVID-19 patient suffering from severe ARDS. Oxygen delivery by VVECMO was optimized to compensate for the increased $\mathrm{O}_{2}$ demand as observed in indirect calorimetry, for successful management and survival.

While young COVID-19 patients rarely develop critically ill conditions, $(5,12)$ obesity $\left(\mathrm{BMI} \geqq 30 \mathrm{~kg} / \mathrm{m}^{2}\right)$ has been observed in $46 \%$ of the critically ill COVID-19 patients (5). The current case had BMI of $31.9 \mathrm{~kg} / \mathrm{m}^{2}$ and presented bilateral ground-glass opacities and patchy consolidation on the CT scan, typical of acute respiratory distress syndrome in COVID-19 with reduced lung compliance (13). Although VV-ECMO is indicated, mortality for COVID-19 patients with severe respiratory failure has been reported to be as high as $50 \%$ (7). Appropriate management of ECMO is essential for the safety and efficacy of the treatment, thus survival of the patients (11). 
While oxygenation failure can only be evaluated passively by the amount of $\mathrm{O}_{2}$ supplementation required to maintain adequate blood oxygen levels, $\mathrm{O}_{2}$ consumption can be measured by indirect calorimetry, a method to measure $\mathrm{VO}_{2}$ and carbon dioxide production $\left(\mathrm{VCO}_{2}\right)$ by respiratory gas analysis to calculate energy expenditure (14). Oxygen demand in critically ill COVID-19 patients has not been well described, with only one study reporting a median REE of $4044 \mathrm{kcal} /$ day in seven critically ill patients without ECMO, corresponding to $\mathrm{VO}_{2}$ of $585 \mathrm{~mL} / \mathrm{min}(18)$, more than twice the average $(270 \mathrm{~mL} / \mathrm{min})$ reported in critically ill patients (15). The elevated demand for oxygen is likely to be sustained during the course of respiratory failure, leading to the need for $\mathrm{VV}$-ECMO and additional measures to increase the efficacy of $\mathrm{O}_{2}$ delivery $(17,19)$. As indirect calorimetry is not readily available for patients under $\operatorname{ECMO}(19,20)$, it is recommended to conduct calorimetry soon after initiation of mechanical ventilation to optimize $\mathrm{O}_{2}$ delivery according to the $\mathrm{O}_{2}$ demand.

Indirect calorimetry was conducted in the present case on the $3^{\text {rd }}$ and $6^{\text {th }}$ ICU days, before the initiation of VV-ECMO. $\mathrm{VO}_{2}$ reached $380 \mathrm{ml} / \mathrm{min}$ while being deeply sedated at RASS -5 . The REE of $2583 \mathrm{kcal} / \mathrm{d}$ corresponds to 1.6 times the energy requirements calculated by the Harris-Benedict equation using ideal body weight $(1563 \mathrm{kcal} / \mathrm{d})$, comparable to stress factor for calculating energy demands in $50 \%$ total body surface area burns. The elevated $\mathrm{VO}_{2}$ persisted until the $6^{\text {th }} \mathrm{ICU}$ day, reflecting the sustained $\mathrm{O}_{2}$ demand. Increasing $\mathrm{O}_{2}$ delivery with $\mathrm{VV}$-ECMO was required to maintain systemic oxygenation, under normal temperature management with ECMO and efforts to reduce $\mathrm{O}_{2}$ consumption by administering sedatives and neuromuscular blockers to achieve RASS -5. Since increasing the ECMO flow induced hemolysis despite the use of large bore catheters (25Fr for drainage and 19Fr for outflow) and no obvious signs of suck down or clot formation in the circuit and the artificial lung, blood hemoglobin level was elevated to increase the blood oxygen capacity and thus the $\mathrm{O}_{2}$ delivery (17).

In conclusion, we experienced a COVID-19 patient with severe ARDS, successfully managed by VV-ECMO. While VV-ECMO was an effective salvage treatment for respiratory failure despite vigorous mechanical ventilation, measures to enhance oxygen delivery was crucial to compensate for the elevated $\mathrm{O}_{2}$ demand. Measuring $\mathrm{O}_{2}$ consumption by indirect calorimetry can elucidate the oxygen demand for optimizing the oxygenation therapy for successful management and survival of critically ill COVID-19 patients.

\section{List Of Abbreviations}

COVID-19, Coronavirus disease 2019; ARDS, acute respiratory distress syndrome; $\mathrm{O}_{2}$ oxygen; NO, nitric oxide; ECMO, extracorporeal membrane oxygenation; $\mathrm{BMI}$, body mass index; $\mathrm{CT}$, computed tomography; $I C U$, intensive care unit; $\mathrm{REE}$, resting energy expenditure; $\mathrm{VO}_{2}, \mathrm{O}_{2}$ consumption volume; PEEP, positive endexpiratory pressure; $\mathrm{VV}$, veno-venous; $\mathrm{VCO}_{2}$, carbon dioxide production.

\section{Declarations}

Ethics approval and consent to participate: Not applicable 
Consent for publication: We have obtained consent for publication from the patient's family.

Availability of data and materials: The patient data obtained from a medical record are available through the corresponding author upon a reasonable request.

Competing interests: The authors declare no conflict of interests related to the current case report.

Funding: None

\section{Authors' contributions:}

Acquisition of data: $\mathrm{YH}$

Drafting of the manuscript: MY, AH, NT, TO

Critical revision of the manuscript for important intellectual content: NT, TO, TO, TN

Supervision: TN

All authors have read and approved the final manuscript.

Acknowledgements: Not applicable

\section{References}

1. Grasselli G, Zangrillo A, Zanella A, Antonelli M, Cabrini L, Castelli A, et al. Baseline Characteristics and Outcomes of 1591 Patients Infected With SARS-CoV-2 Admitted to ICUs of the Lombardy Region, Italy. Jama. 2020;323(16):1574-81.

2. Guan WJ, Ni ZY, Hu Y, Liang WH, Ou CQ, He JX, et al. Clinical Characteristics of Coronavirus Disease 2019 in China. N Engl J Med. 2020;382(18):1708-20.

3. Richardson S, Hirsch JS, Narasimhan M, Crawford JM, McGinn T, Davidson KW, et al. Presenting Characteristics, Comorbidities, and Outcomes Among 5700 Patients Hospitalized With COVID-19 in the New York City Area. Jama. 2020;323(20):2052-9.

4. Bhatraju PK, Ghassemieh BJ, Nichols M, Kim R, Jerome KR, Nalla AK, et al. Covid-19 in Critically III Patients in the Seattle Region - Case Series. N Engl J Med. 2020;382(21):2012-22.

5. Cummings MJ, Baldwin MR, Abrams D, Jacobson SD, Meyer BJ, Balough EM, et al. Epidemiology, clinical course, and outcomes of critically ill adults with COVID-19 in New York City: a prospective cohort study. Lancet. 2020;395(10239):1763-70.

6. Yang X, Yu Y, Xu J, Shu H, Xia J, Liu H, et al. Clinical course and outcomes of critically ill patients with SARS-CoV-2 pneumonia in Wuhan, China: a single-centered, retrospective, observational study. Lancet Respir Med. 2020;8(5):475-81. 
7. Li X, Guo Z, Li B, Zhang X, Tian R, Wu W, et al. Extracorporeal Membrane Oxygenation for Coronavirus Disease 2019 in Shanghai, China. Asaio j. 2020;66(5):475-81.

8. Giamarellos-Bourboulis EJ, Netea MG, Rovina N, Akinosoglou K, Antoniadou A, Antonakos N, et al. Complex Immune Dysregulation in COVID-19 Patients with Severe Respiratory Failure. Cell Host Microbe. 2020;27(6):992-1000.e3.

9. Tay MZ, Poh CM, Rénia L, MacAry PA, Ng LFP. The trinity of COVID-19: immunity, inflammation and intervention. Nat Rev Immunol. 2020;20(6):363-74.

10. Komindr A, Abe R, Tateishi Y, Takahashi Y, Goto J, Wada K, et al. Establishing extracorporeal membrane oxygenation team increased number of patients and improved data recording. $J$ Intensive Care. 2019;7:11.

11. Kowalewski M, Fina D, Słomka A, Raffa GM, Martucci G, Lo Coco V, et al. COVID-19 and ECMO: the interplay between coagulation and inflammation-a narrative review. Crit Care. 2020;24(1):205.

12. Argenziano MG, Bruce SL, Slater CL, Tiao JR, Baldwin MR, Barr RG, et al. Characterization and clinical course of 1000 patients with coronavirus disease 2019 in New York: retrospective case series. Bmj. 2020;369:m1996.

13. Gattinoni L, Chiumello D, Rossi S. COVID-19 pneumonia: ARDS or not? Crit Care. 2020;24(1):154.

14. Oshima $T$, Berger MM, De Waele E, Guttormsen AB, Heidegger $C P$, Hiesmayr $M$, et al. Indirect calorimetry in nutritional therapy. A position paper by the ICALIC study group. Clin Nutr. 2016. doi:10.1016/j.clnu.2016.06.010. [Epub ahead of print].

15. Oshima T, Ragusa M, Graf S, Dupertuis YM, Heidegger CP, Pichard C. Methods to validate the accuracy of an indirect calorimeter in the in-vitro setting. Clinical nutrition ESPEN. 2017;22:71-5.

16. Singer P, Blaser AR, Berger MM, Alhazzani W, Calder PC, Casaer MP, et al. ESPEN guideline on clinical nutrition in the intensive care unit. Clin Nutr. 2019;38(1):48-79.

17. Spinelli E, Bartlett RH. Relationship between hemoglobin concentration and extracorporeal blood flow as determinants of oxygen delivery during venovenous extracorporeal membrane oxygenation: a mathematical model. Asaio j. 2014;60(6):688-93.

18. Yu PJ, Cassiere H, DeRosa S, Bocchieri K, Yar S, Hartman A. Hypermetabolism and COVID-19. JPEN J Parenter Enteral Nutr. 2020.

19. Cheypesh A, Yu X, Li J. Measurement of systemic oxygen consumption in patients during extracorporeal membrane oxygenation-description of a new method and the first clinical observations. Perfusion. 2014;29(1):57-62.

20. De Waele E, van Zwam K, Mattens S, Staessens K, Diltoer M, Honore PM, et al. Measuring resting energy expenditure during extracorporeal membrane oxygenation: preliminary clinical experience with a proposed theoretical model. Acta Anaesthesiol Scand. 2015;59(10):1296-302.

\section{Tables}

Table 1. Laboratory data on ICU admission day 


\begin{tabular}{llllll}
\hline Hematology & \multicolumn{5}{c}{ Biochemistry } \\
\hline WBC & 11400 & $/ \mathrm{mm}^{3}$ & AST & 79 & $\mathrm{IU} / \mathrm{L}$ \\
RBC & $430 \times 10^{4}$ & $/ \mathrm{mm}^{3}$ & ALT & 78 & $\mathrm{IU} / \mathrm{L}$ \\
Hemoglobin & 13.0 & $\mathrm{~g} / \mathrm{dL}$ & $\mathrm{LDH}$ & 545 & $\mathrm{IU} / \mathrm{L}$ \\
Hematocrit & 38.1 & $\%$ & ALP & 218 & $\mathrm{U} / \mathrm{L}$ \\
Platelet & $19.3 \times 10^{4}$ & $/ \mathrm{mm}^{3}$ & TP & 5.8 & $\mathrm{~g} / \mathrm{dL}$ \\
& & & Albumin & 2.7 & $\mathrm{~g} / \mathrm{dL}$ \\
& & UN & 8 & $\mathrm{mg} / \mathrm{dL}$ \\
& & & Creatinin & 0.74 & $\mathrm{mg} / \mathrm{dL}$ \\
& & & T-Bil & 0.6 & $\mathrm{mg} / \mathrm{dL}$ \\
Coagulation & system & & D-Bil & 0.2 & $\mathrm{mg} / \mathrm{dL}$ \\
& & & Amylase & 190 & $\mathrm{IU} / \mathrm{L}$ \\
PT & 11.2 & $\mathrm{sec}$ & CPK & 643 & $\mathrm{IU} / \mathrm{L}$ \\
PT\% & 87 & $\%$ & CRP & 16.9 & $\mathrm{mg} / \mathrm{dL}$ \\
PT-INR & 1.02 & & Glucose & 106 & $\mathrm{mg} / \mathrm{dL}$ \\
APTT & 34.0 & $\mathrm{sec}$ & Sodium & 131 & $\mathrm{mEq} / \mathrm{L}$ \\
FDP & 2.8 & $\mu \mathrm{g} / \mathrm{mL}$ & Potassium & 4.2 & $\mathrm{mEq} / \mathrm{L}$ \\
Fibrinogen & 479 & $\mathrm{mg} / \mathrm{dL}$ & Chloride & 100 & $\mathrm{mEq} / \mathrm{L}$ \\
& & & Calcium & 7.4 & $\mathrm{mg} / \mathrm{dL}$
\end{tabular}

\begin{tabular}{lll}
\hline Others & & \\
\hline Interleukin-6 & 164.3 & $\mathrm{pg} / \mathrm{mL}$ \\
Procalcitonin & 0.46 & $\mathrm{ng} / \mathrm{mL}$ \\
Ferritin & 1225 & $\mathrm{ng} / \mathrm{mL}$
\end{tabular}

\begin{tabular}{|c|c|c|c|c|}
\hline \multicolumn{3}{|c|}{ Blood gas analysis } & \multicolumn{2}{|l|}{ Culture } \\
\hline \multirow{5}{*}{$\begin{array}{l}\mathrm{pH} \\
\mathrm{PaO}_{2} \\
\mathrm{PaCO}_{2} \\
\mathrm{HCO}^{3-} \\
\mathrm{BE} \\
\text { Lactate }\end{array}$} & \multirow{5}{*}{$\begin{array}{l}7.39 \\
58 \\
39 \\
23.6 \\
-1.2 \\
0.9\end{array}$} & \multirow{5}{*}{$\begin{array}{l}\mathrm{mmHg} \\
\mathrm{mmHg} \\
\mathrm{mmol} / \mathrm{L} \\
\mathrm{mmol} / \mathrm{L} \\
\mathrm{mmol} / \mathrm{L}\end{array}$} & Blood & Negative \\
\hline & & & Sputum & Negative \\
\hline & & & & \\
\hline & & & Urinary antigen test & \\
\hline & & & $\begin{array}{l}\text { Streptococcus pneumoniae } \\
\text { Legionella }\end{array}$ & $\begin{array}{l}\text { Negative } \\
\text { Negative }\end{array}$ \\
\hline
\end{tabular}

WBC: white blood cell, RBC: red blood cell, PT: prothrombin time, INR: international normalized ratio, APTT: activated partial thromboplastin time, FDP: fibrin degradation products, BE: base excess, AST: aspartate aminotransferase, ALT: alanine aminotransferase, LDH: lactate dehydrogenase, ALP: alkaline phosphatase, TP: total protein, UN: urea nitrogen, T-Bil: total bilirubin, D-Bil: direct bilirubin, CPK: creatine phosphokinase, CRP: C-reactive protein

Table 2. Results of indirect calorimetry and vital signs during the measurement. 


\begin{tabular}{|c|c|c|c|c|c|c|c|c|c|}
\hline \multicolumn{2}{|l|}{ ICU day } & \multicolumn{6}{|c|}{3} & \multicolumn{2}{|c|}{6} \\
\hline Duration & $(\min )$ & 15 & 30 & 45 & 60 & 75 & 90 & 15 & 30 \\
\hline REE & (kcal/day) & 1879 & 1842 & 1903 & 1946 & 2049 & 2583 & 2530 & 2548 \\
\hline RQ & & 0.65 & 0.70 & 0.72 & 0.68 & 0.64 & 0.70 & 0.62 & 0.64 \\
\hline VO2 & $(\mathrm{mL} / \mathrm{min})$ & 280 & 271 & 279 & 288 & 306 & 380 & 380 & 380 \\
\hline VCO2 & $(\mathrm{mL} / \mathrm{min})$ & 182 & 190 & 201 & 196 & 196 & 266 & 235 & 243 \\
\hline Heart rate & (bpm) & 63 & 61 & 63 & 63 & 68 & 74 & 68 & 68 \\
\hline $\mathrm{SpO}_{2}$ & (\%) & 95 & 95 & 95 & 99 & 85 & 77 & 94 & 94 \\
\hline Body temperature & $\left({ }^{\circ} \mathrm{C}\right)$ & 38.5 & 38.5 & 38.5 & 38.5 & 38.6 & 38.6 & 38.0 & 38.2 \\
\hline Respiratory rate & $(/ \min )$ & 25 & 24 & 25 & 23 & 40 & 48 & 24 & 25 \\
\hline Minute volume & (L/min) & 8.4 & 8.2 & 8.9 & 7.8 & & 14.0 & 10.2 & 10.4 \\
\hline RASS & & & & & & & & & \\
\hline
\end{tabular}

REE: resting energy expenditure; RQ: respiratory quotient; $\mathrm{VO}_{2}$ : volume of oxygen consumption, $\mathrm{VCO}_{2}$ : volume of carbon dioxide production; $\mathrm{SpO}_{2}$ : oxygen saturation; RASS: Richmond Agitation-Sedation Scale

Figures
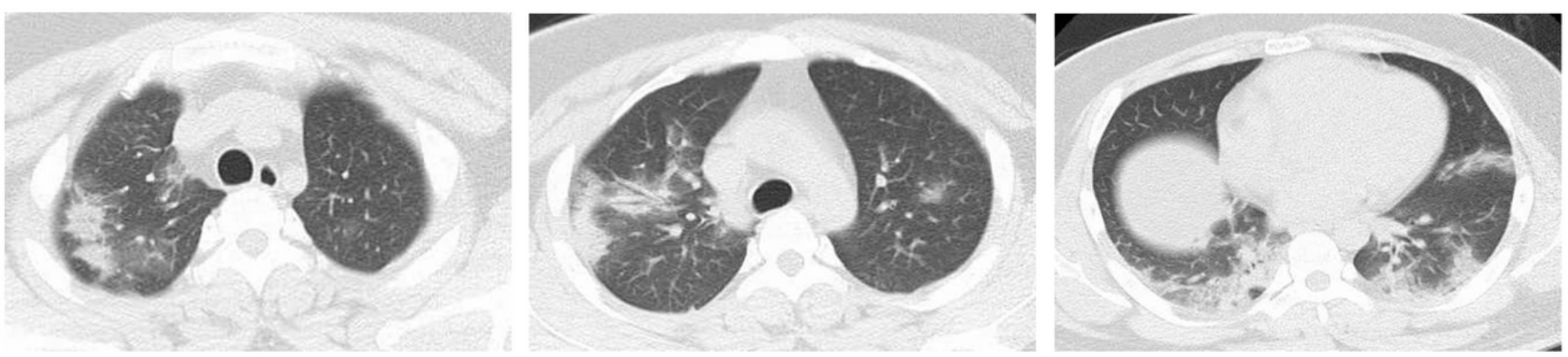

a) $1^{\text {st }}$ Hospital Day
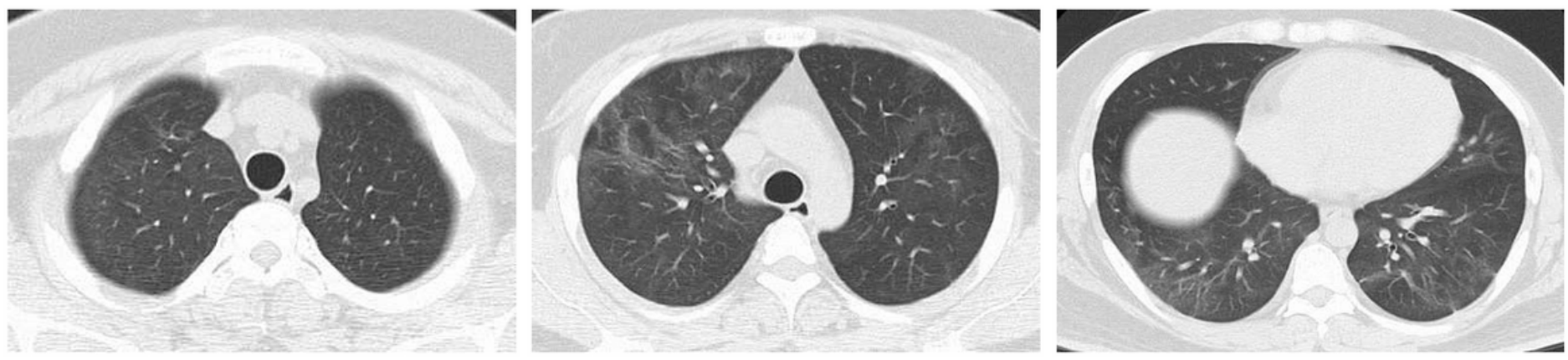

b) $45^{\text {th }}$ Hospital day

\section{Figure 1}

Lung CT Scan on admission and before discharge. a) Bilateral ground glass opacities and patchy consolidations typical of COVID-19 pneumonia was observed on admission. b) The initial findings have 
resolved with slight remains of ground glass appearance by the day before discharge.

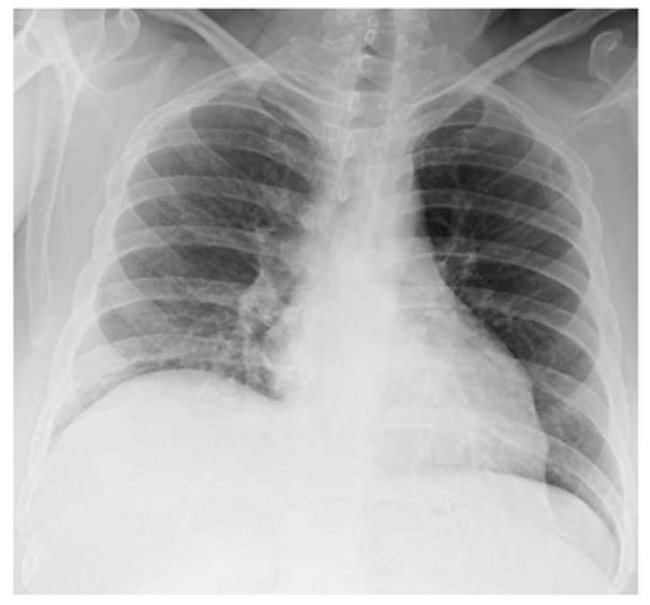

a) $1^{\text {st }}$ Hospital day

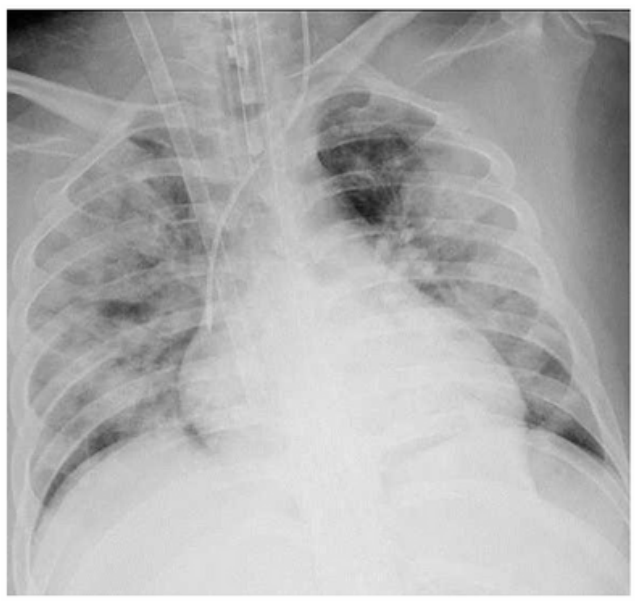

b) $9^{\text {th }}$ Hospital $\left(7^{\text {th }}\right.$ ICU) day

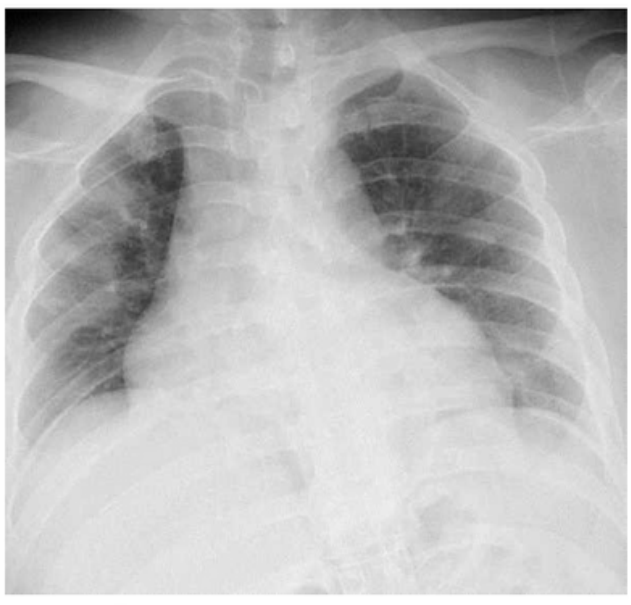

c) $43^{\text {rd }}$ Hospital day

\section{Figure 2}

Chest x-ray progression during the hospital stay. a) Minor shadows observed in the lower lobes on hospital admission. b) Severe bilateral infiltration progressed with the deterioration of respiratory function, requiring VV- ECMO. c) Although slight bilateral shadows remain, respiratory function sufficiently recovered, no longer requiring oxygen supplementation at the time of hospital discharge. 